\title{
Food-niche pattern of the Barn Owl (Tyto alba) in intensively cultivated agricultural landscape ${ }^{x}$
}

\section{Adrienn Horváth, Anita Morvai \& Győző F. Horváth*}

Received: February 28, 2018 -Revised: June 13, 2018 -Accepted: June 15, 2018

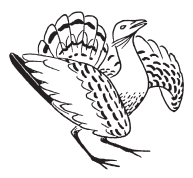

Horváth, A., Morvai, A. \& Horváth, G. F. 2018. Food-niche pattern of the Barn Owl (Tyto alba) in intensively cultivated agricultural landscape. - Ornis Hungarica 26(1): 27-40. DOI: 10.1515/ orhu-2018-0002

${ }^{\times}$Presented at $1^{\text {st }}$ Hungarian Owl Research Conference held in Pécs on $8^{\text {th }}$ September 2017

\begin{abstract}
This study investigated the dietary niche of the Barn Owl (Tyto alba) in an intensively farmed landscape, based on pellet samples from 12 nesting pairs containing 25 animal taxa and 1,994 prey items after the breeding season in 2016. Based on land use categories of the buffer area around each nest, three landscape types (agricultural, mosaic, urban) were considered, to analyse the diet composition and food-niche parameters. Niche breadth was calculated at the local and landscape level. Small mammals were the most frequent in the diet than other prey in each of the landscape types. The Common Vole (Microtus arvalis), considered to be an important agricultural pest was the most numerous prey in all landscape groups. The trophic niche of Barn Owl varied between $0.69-0.86$ at the local level, and the overall value of niche breadth was significantly higher in the urban than in the other two landscape types. Our results showed that the increase of Common Vole frequency lead to a decrease in niche breadth; significantly negative relationship was detected between these parameters. Despite differences in niche breadth, similarly high niche overlaps were detected by the randomisation test in the three landscapes. Our results suggest that the diet composition of Barn Owls, mainly their food-niche pattern, reflected prey availability in the comparison of the studied landscapes, which pointed out that it is necessary to examine the dietary difference of Barn Owls at the finer scale of land use.
\end{abstract}

Keywords: feeding ecology, niche breadth, pellet analysis, land use

Összefoglalás Jelen tanulmányban a gyöngybagoly (Tyto alba) táplálék-összetételét intenzíven múvelt mezőgazdasági területen vizsgáltuk. A 2016-ban gyüjtött, 12 költőpártól származó köpetminta összesen 25 zsákmány taxon 1994 egyedét tartalmazta. Az egyes fészkelőhelyek körüli pufferterület tájhasználati kategóriái alapján három tájtípust (mezőgazdasági, mozaikos, urbán) különítettünk el, hogy vizsgáljuk a gyöngybagoly táplálék-összetételét és niche paramétereit. A niche szélességet a települések alapján lokális és tájszinten elemeztük. Minden egyes tájtípusban a kisemlősök domináltak a baglyok táplálék-összetételében, míg egyéb prédafajok alacsony gyakoriságban jelentek meg. Mindhárom településcsoport esetében a mezei pocok (Microtus arvalis), mint jelentős mezőgazdasági kártevő volt a leggyakoribb zsákmány. A niche-szélesség lokális szinten 0,69-0,86 között változott, az összesített adatok alapján a niche-szélesség szignifikánsan nagyobb volt az agrárdominanciájú, mint a másik két településcsoport vonatkozásában. Eredményeink alapján a mezei pocok gyakoriságának növekedése a niche-szélesség csökkenéséhez vezetett, a két paraméter között szignifikáns negatív regressziót mutattunk ki. A niche-szélesség eltérésének ellenére, a randomizációs teszt alapján hasonlóan magas niche-átfedést mutattuk ki a három tájtípus összehasonlításában. Eredményeink azt sugallják, hogy a gyöngybaglyok táplálék-összetétele, fóként a táplálék niche mintázat a vizsgált tájegységek összehasonlításában visszatükrözte a zsákmány-elérhetőséget, amely rámutatott arra, hogy a gyöngybagoly táplálék-összetétel különbségét a tájhasználat finomabb skáláján szükséges vizsgálni.

Kulcsszavak: táplálkozás ökológia, niche-szélesség, köpetanalízis, tájhasználat

University of Pécs, Faculty of Sciences, Institute of Biology, Department of Ecology, 7624 Pécs, Ifjúság utca 6., Hungary,e-mail:hgypte@gamma.ttk.pte.hu

* corresponding author 


\section{Introduction}

Barn Owl (Tyto alba) as cosmopolitan nocturnal predator occurs worldwide in most open lands and farmlands (de Bruijn 1994, Taylor 1994, Charter et al. 2009, Frey et al. 2011) and its diet composition is influenced by the fluctuation of prey populations (Campbell et al. 1987, Taylor 1994, Bernard et al. 2010, Paspali et al. 2013), climatic factors (Clark \& Bunck 1991, Avery 1999, Heisler et al. 2014), and change of land use and landscape composition (Rodríguez \& Peris 2007, Milchev 2015, Veselovský et al. 2017).

Since the classical trophic niche studies of owls (Marti 1974, Herrera 1974, Herrera \& Hiraldo 1976) the food-niche difference of Barn Owls has been investigated in several approaches such as through comparative intra- and interspecific feeding ecology (Herrera \& Jaksić 1980, Capizzi \& Luiselli 1998, Leader et al. 2010, Petrovici et al. 2013, Milchev 2016), trophic guild structure (Jaksić \& Delibes 1987, Jaksić et al. 1993), long-term study of food composition (Marti 1988, 2010, Love et al. 2000), along different geographical regions (Jaksić et al. 1982, González-Fischer et al. 2011, Milana et al. 2016), and gradients (Leveau et al. 2006, Trejo \& Lambertucci 2007, Hindmarch \& Elliott 2015), as well as the impact of disturbances (Jaksić et al. 1997, Sahores \& Trejo 2004) particularly dependence on growing agricultural activity and changes in farming practice (Love et al. 2000, de la Peña et al. 2003, Bontzorlos et al. 2005, Marti 2010).

Different results of Barn Owls' food-niche analyses have been demonstrated in agricultural ecosystems, and these depended on geographical regions and seasons. Niche breadth was different between seasons in Mediterranean areas (Pezzo \& Morimando 1995, Bontzorlos et al. 2005), while the niche overlap was high in comparison between seasons (Pezzo \& Morimando 1995), and between nest sites (Bosè \& Guidali 2001). The food-niche breadth of Barn Owls varied significantly among the years but was not statistically different among seasons in a North American agricultural landscape (Marti 2010), although the seasonal difference of niche breadth was more detectable in temperate regions (Campbell et al. 1987, Taylor 1994, González-Fischer et al. 2011). Despite this seasonal variation, no correlation was observed between food niche breadth and latitude or longitude, but the prey selection of Barn Owls was associated with the rodent assemblages and responded to the abundance fluctuation of rodents along the gradients in South-America (Leveau et al. 2006, Trejo \& Lambertucci 2007, González-Fischer et al. 2011). The relationship between density fluctuation of small mammals and diet composition was investigated in the Nearctic (Campbell et al. 1987, Marti 1988, 2010) and Palearctic range of the Barn Owl (Taylor 1994, Bernard et al. 2010). According to these studies, the variation of the Barn Owl's prey consumption was basically determined by high density open-field and agricultural pest rodents, such as species of Microtus in both distribution ranges of the Northern Hemisphere. The negative correlation between vole (Microtus spp.) frequency and food-niche breadth of the Barn Owl was demonstrated by long-term (Marti 1988, 2010) and other case studies (Milchev 2015, Hindmarch \& Elliott 2015). Furthermore, the food-niche breadth of Barn Owl decreased significantly with the increase of mean prey weight (Marti 1988, Milchev 2015), and a significant positive regression was found between the sample size and niche breadth values (Milana et al. 2016). 
Several studies suggested that the yearly and seasonal variations in the diet composition and thus the plasticity of the food-niche breadth of the Barn Owl reflected local resource conditions, especially the density fluctuation of small mammal preys and changes in the composition of the small mammal assemblages (Milana et al. 2016). The population and community attributes of this main prey groups of Barn Owls were determined by changes in the vegetation cover (Lovari et al. 1976, Marti 1988, Pezzo \& Morimando 1995, Bontzorlos et al. 2005), land use and agricultural activity (crop rotation, frequency of mowing or harvesting) (Cooke et al. 1996, Askew et al. 2007).

In the present study we investigate the hypothesis that habitat variation at the local spatial scale influences the diet composition of Barn Owls, while according to alternative hypothesis, the prey consumption and niche breadth do not depend on the local environmental heterogeneity due to the dominance of intensively cultivated agricultural areas at the regional scale. Our objectives were: i) to evaluate the diet composition of Barn Owls and the relative abundance of small mammals, and ii) to investigate difference of food-niche breadth at the local and landscape scale and niche overlap between three distinguished landscape types within the intensively cultivated agricultural area.

\section{Material and methods}

\section{Study area and sample collection}

The study was conducted in the intensively cultivated south-eastern part of Transdanubian region in South Hungary $\left(572.3 \mathrm{~km}^{2}\right)$ in Baranya county $\left(45^{\circ} 53^{\prime} \mathrm{N}, 18^{\circ} 20^{\prime}\right.$ E) (Figure 1). The climate of this region is characterising by the Mediterranean influence with the high number of sunny hours, the relative low fluctuations of temperatures and mild winters. In the present study pellets and prey remains were collected from 12 Barn Owl pairs from the sampling sites at the end of the breeding season in 2016. As a result of a successful artificial nest box program in this county the collection of pellet samples was implemented from active next boxes in each locality. Landscape compositions were assessed using Google Earth (2013) and landscape elements were analysed within a $1 \mathrm{~km}$ radius around each nest site because this corresponds to an area that approximates the home range $\left(3 \mathrm{~km}^{2}\right)$ of a Barn Owl during the breeding season (e.g. Taylor 1994, Hindmarch et al. 2012, Kross et al. 2016). Three groups of the nesting sites (4 sampling localities/group) were distinguished based on landscape composition: 1) agricultural landscape (AL), 2) mosaic landscape (ML), and 3) urban landscape (UL). The following land-use types were identified and digitized, then the percentage of these categories were calculated: 1) agricultural field (annual and perennial crops); 2) extensive land use (grassland, pasture, orchards, vineyards); 3) wetland (including river banks, streams, artificial lakes, fishponds); 4) forest (all forest habitats), and 5) urban (all built-up surfaces) areas (Table 1).

Pellets were processed by the dry technique when the individual pellets were broken down by hand and prey items were identified to the lowest possible taxonomical level. Small mammals were identified based on skeletal parameters (features of skull, mandible and teeth), 


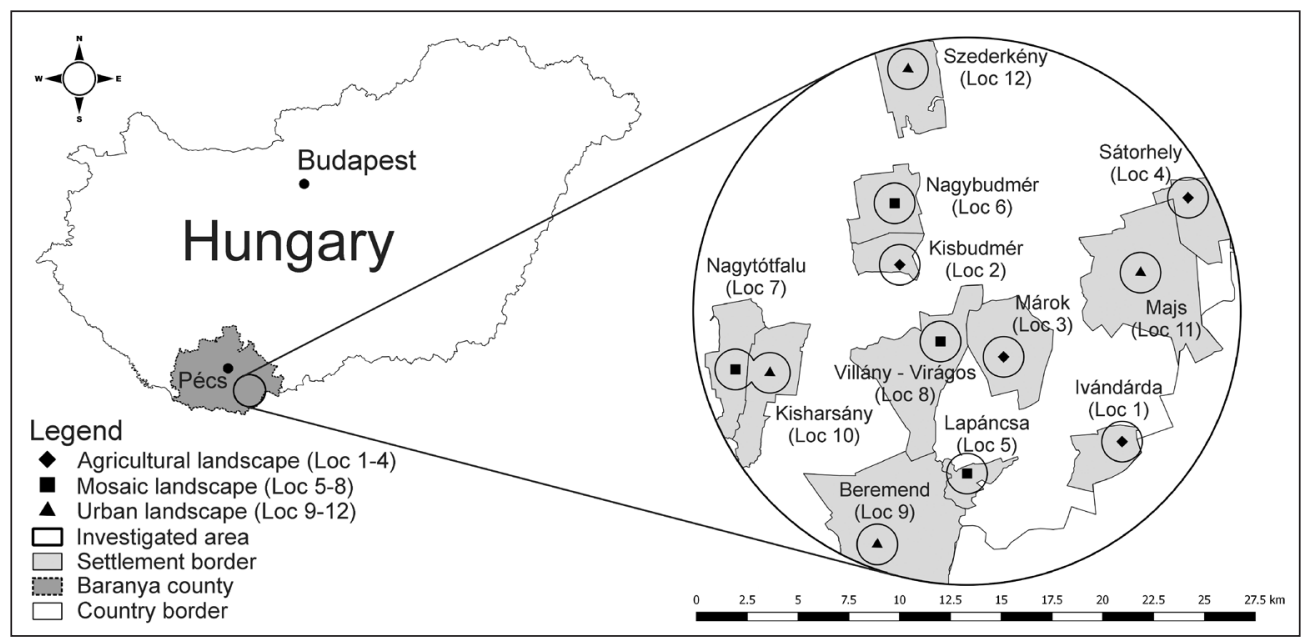

Figure 1. Study area in the South-Transdanubian region, Hungary, showing the location of Baranya county and 12 nesting pairs within the examined landscape. Code numbers (Loc1-12) besides settlement names correspond to those in Table 3 .

1. ábra A vizsgált terület Dél-Dunántúlon, Magyarországon, feltűntetve Baranya megye és a 12 költőpár elhelyezkedését a vizsgált tájegységen belül. A településnevek melletti (Loc1-12) kódszámok a 3. táblázatban szereplő kódolásnak felelnek meg

following published literature (März 1972, Yalden 1977, Yalden \& Morris 1990). Three different Apodemus species as the Wood Mouse (Apodemus sylvaticus), the Yellow-necked Wood Mouse (A. flavicollis) and the Pygmy Field Mouse (A. uralensis) were categorized commonly as Apodemus spp. When the Striped Field Mouse (A. agrarius) was not separable from the Sylvaemus group (Apodemus spp.) the individuals were determined as 'unidentified Apodemus'. The sibling species of the genus Mus were determined according to Macholán (1996) and Kryštufek and Macholán (1998). In addition, birds were identified by their skulls, bills, feet, pelvises and feathers, and frog (Anura) by their skulls and bones of the postcranial skeleton. If major skeletal elements were missing, prey items were identified to genus (small mammals, birds), to order (frogs), and to class (birds) level.

Table 1. Mean proportions and value ranges (\%) of land use categories in three distinct landscape types

1. táblázat A tájhasználati kategóriák átlagos aránya és érték-intervalluma (\%) a három elkülönített tájtípusban

\begin{tabular}{|l|c|c|c|c|c|c|}
\hline \multicolumn{1}{|c|}{ Landscape } & \multicolumn{2}{c|}{ Agricultural } & \multicolumn{2}{c|}{ Mosaic } & \multicolumn{2}{c|}{ Urban } \\
\hline \multicolumn{1}{|c}{ Land use } & Mean \pm SE & Range $\%$ & Mean \pm SE & Range $\%$ & Mean \pm SE & Range $\%$ \\
\hline agricultural field & $72.20 \pm 1.27$ & $69.04-75.19$ & $58.35 \pm 5.26$ & $46.45-70.19$ & $31.48 \pm 6.16$ & $16.86-45.35$ \\
\hline extensive land use & $7.08 \pm 3.12$ & $0.43-13.53$ & $16.85 \pm 8.02$ & $5.07-39.47$ & $19.15 \pm 6.97$ & $10.96-39.99$ \\
\hline wetland & $1.13 \pm 0.55$ & $0.42-2.75$ & $1.71 \pm 1.10$ & $0-4.59$ & $0.47 \pm 0.40$ & $0-1.66$ \\
\hline forest & $7.85 \pm 3.84$ & $1.67-18.95$ & $13.99 \pm 3.15$ & $4.91-18.77$ & $13.20 \pm 2.97$ & $4.33-16.87$ \\
\hline urban areas & $11.74 \pm 3.69$ & $4.31-21.96$ & $9.10 \pm 0.63$ & $7.33-10.18$ & $35.70 \pm 8.67$ & $18.86-56.1$ \\
\hline
\end{tabular}


Prey numbers were estimated as the minimum number of individuals (MNI) which we determined according to the same anatomical parts of bones for small mammals (Klein \& Cruz-Uribe 1984, McDowell \& Medlin 2009, Torre et al. 2015, Tulis et al. 2015) and skulls, mandibles and long bones for birds. The percent frequency of occurrence (MNI\%) was calculated for the total number of prey found in all the pellets at the three different landscape categories.

\section{Statistical methods}

First, we evaluated the difference of the relative abundance (MNI\%) of small mammals among the separated landscape types. The arithmetic mean MNI\% is presented with standard error. To test the hypothetic relationship between niche breadth and Common Vole (Microtus arvalis) frequency, linear regression method was used. These statistical analyses were performed using Statistica 8.0 software (StatSoft, Bedford, UK).

The food-niche breadth of Barn Owls was calculated by the Freeman-Tukey index (FT) from data of each nesting pair at the local scale and from the overall data of three different landscapes using the relative frequency of occurrence of food items which were identified in the pellets:

$$
F T=\sum_{i=1}^{R} \sqrt{p_{i} a_{i}}
$$

where $F T$ is Smith's measure of niche breadth (Smith 1982), $p_{i}$ is the proportion of individuals found using resource $i$, and $a_{i}$ is the proportion of resource $i$ of the total resources $(R)$ found in a given summarized pellet sample. Smith's niche breadth is a standardized measure, as it takes resource availability into account (Devictor et al. 2010). The value of this index varies from 0 (minimal) to 1.0 (maximal) and it is relatively insensitive to selectivity for rare resources and to evaluate the significant difference of niche breadth, $95 \%$ confidence interval of $F T$ values was calculated which measures the uncertainty of estimates (Krebs 1999).

To evaluate the food niche overlap of the Barn Owl among different landscapes, the Pianka overlap index $\left(\mathrm{O}_{12}\right.$, Pianka 1974, Krebs 1999) was calculated:

$$
O_{12}=O_{21}=\frac{\sum_{i=1}^{n} p_{2 i} p_{1 i}}{\sqrt{\sum_{i=1}^{n}\left(p_{2 i}^{2}\right) \sum_{i=1}^{n}\left(p_{1 i}^{2}\right)}}
$$

where $p_{i}$ is the frequency of the $i^{\text {th }}$ item in the diet. This index ranges between 0 (no overlap) and 1 (complete overlap). The significance of the overlap was tested using randomization procedures in R v. 3.3.2 (R Development Core Team 2016), using the "EcoSimR" packages (Gotelli et al. 2015). The statistical tests were considered significant at the level $\mathrm{P} \leq 0.05$ as standard in all analyses (Sokal \& Rohlf 1995). 


\section{Results}

The diet composition and feeding range was analysed from a total of 890 pellets from which 258 whole pellets were collected in agricultural, 424 in mosaic and 208 in urban landscape. Based on all samples of 12 nesting Barn Owl pairs, 25 animal taxa and 1,994 prey items were identified from the pellets examined during the nesting period in 2016 (Table 2). Small mammals were more frequent among Barn Owl food types (AL: 98.30\% \pm 1.04 , ML: $99.93 \% \pm 0.07$, UL: $99.40 \% \pm 0.40$ ) while the proportion of other prey categories was very low in each landscape type (AL: $1.70 \% \pm 1.04$, ML: $0.07 \% \pm 0.04$, UL: $0.60 \% \pm 0.39$ ). Rodents (AL: $90.98 \% \pm 2.73$, ML: $88.27 \% \pm 1.88$, UL: $91.76 \% \pm 1.43$ ) were more represented within the small mammals than shrews (AL: $7.31 \% \pm 3.04$, ML: $11.66 \% \pm 1.82$, UL: $7.36 \%$ \pm 1.73 ) in the case of each landscape. The proportion of rodents was quite the same in the landscapes while this value of shrews was higher in mosaic than in the other two landscapes (Table 2).

The Common Vole (M. arvalis) was the most abundant prey in each of the localities of the three landscape types (AL: 55.95\% \pm 9.49 , ML: 45.72\% \pm 4.67 , UL: $43.30 \% \pm 6.09$ ). Despite the predominance of the Common Vole which basically determined the percent frequency of voles (Arvicolinae), the amount of mice (Murinae) as an important alternative prey group was higher in the case of some sampling localities within rodents. At the species level, the percent distribution of the Striped Field Mouse was higher in the area dominated by built-up surfaces $(8.63 \% \pm 0.81)$ than in the agricultural land $(3.75 \% \pm 1.71)$ but the abundance of this species was similar between the urban and mosaic landscapes $(7.53 \%$ \pm 0.77 ) (Table 2).

The calculated Freeman-Tukey index (FT) indicated that the niche breadth of the Barn Owl varied in different intervals within each separated landscape (Table 3). The range of niche breadth of nesting pairs (localities) was greater in the agricultural land while narrower in the mosaic and urban landscapes which were confirmed by the $95 \%$ confidence interval of minimum and maximum values of FT index. The lack of overlap indicated a significant difference between the minimal and maximal values of niche breadth in the case of the agricultural landscape. In contrast, the same narrower range of food-niche breadth was showed by the overlap of $95 \%$ confidence interval of terminal values in the case of other two landscapes (Table 3). Based on results of each nesting pair, a significant negative linear regression was detected between the local abundance of common vole and food-niche breadth $\left(R^{2}\right.$ $=0.659, F=19.39, P<0.01$ ) (Figure 2).

The value of overall niche breadth at the landscape level was significantly higher in the urban than in the agricultural and mosaic landscapes while there was no significant difference between agricultural and mosaic landscapes due to an overlap of $95 \%$ confidence interval (Figure 3).

Despite the difference of overall niche breadth values which was observed between urban and another two landscapes, significantly higher food-niche overlap indices were presented by the randomization procedure in the comparison of all the considered landscapes than the obtained mean values from simulations (Table 4). 
Table 2. Diet composition of the Barn Owl in the three considered landscapes (MNI: minimum number of individuals, MNI\%: percentage frequency of occurrence)

2. táblázat A gyöngybagoly táplálék-összetétele a három figyelembe vett tájegységben (MNI: minimum ismert egyedszám, MNI\%: az előfordulási frekvencia százalékos értéke)

\begin{tabular}{|c|c|c|c|c|c|c|c|c|}
\hline \multirow{2}{*}{$\begin{array}{c}\text { Landscape } \\
\text { Taxa }\end{array}$} & \multicolumn{2}{|c|}{ Agricultural } & \multicolumn{2}{|c|}{ Mosaic } & \multicolumn{2}{|c|}{ Urban } & \multicolumn{2}{|c|}{ Total } \\
\hline & $\mathrm{MNI}$ & MNI\% & MNI & MNI\% & MNI & $\mathrm{MNI} \%$ & MNI & MNI\% \\
\hline Soricidae & 40 & 8.03 & 118 & 12.25 & 52 & 9.76 & 210 & 10.53 \\
\hline Sorex araneus & 1 & 0.20 & 11 & 1.14 & 6 & 1.13 & 18 & 0.90 \\
\hline Sorex minutus & 1 & 0.20 & 2 & 0.21 & 2 & 0.38 & 5 & 0.25 \\
\hline Neomys fodiens & 2 & 0.40 & 14 & 1.45 & 4 & 0.75 & 20 & 1.00 \\
\hline Neomys anomalus & 3 & 0.60 & 13 & 1.35 & 8 & 1.50 & 24 & 1.20 \\
\hline Neomys sp. & 3 & 0.60 & 2 & 0.21 & 3 & 0.56 & 8 & 0.40 \\
\hline Crocidura suaveolens & 14 & 2.81 & 47 & 4.88 & 14 & 2.63 & 75 & 3.76 \\
\hline Crocidura leucodon & 16 & 3.21 & 29 & 3.01 & 15 & 2.81 & 60 & 3.01 \\
\hline Arvicolinae & 314 & 63.05 & 476 & 49.43 & 233 & 43.71 & 1023 & 51.30 \\
\hline Myodes glareolus & 0 & 0.00 & 6 & 0.62 & 3 & 0.56 & 9 & 0.45 \\
\hline Microtus agrestis & 2 & 0.40 & 1 & 0.10 & 0 & 0.00 & 3 & 0.15 \\
\hline Microtus arvalis & 301 & 60.44 & 456 & 47.35 & 216 & 40.53 & 973 & 48.80 \\
\hline Microtus subterraneus & 6 & 1.20 & 3 & 0.31 & 8 & 1.50 & 17 & 0.85 \\
\hline Arvicola amphibius & 5 & 1.00 & 10 & 1.04 & 6 & 1.13 & 21 & 1.05 \\
\hline Murinae & 142 & 28.51 & 364 & 37.80 & 236 & 44.28 & 742 & 37.21 \\
\hline Rattus norvegicus & 0 & 0.00 & 0 & 0.00 & 3 & 0.56 & 3 & 0.15 \\
\hline Rattus sp. & 4 & 0.80 & 12 & 1.25 & 22 & 4.13 & 38 & 1.91 \\
\hline Apodemus agrarius & 16 & 3.21 & 74 & 7.68 & 48 & 9.01 & 138 & 6.92 \\
\hline Apodemus spp. & 65 & 13.05 & 150 & 15.58 & 109 & 20.45 & 324 & 16.25 \\
\hline Apodemus indet & 26 & 5.22 & 59 & 6.13 & 20 & 3.75 & 105 & 5.27 \\
\hline Micromys minutus & 6 & 1.20 & 18 & 1.87 & 1 & 0.19 & 25 & 1.25 \\
\hline Mus spicilegus & 10 & 2.01 & 20 & 2.08 & 13 & 2.44 & 43 & 2.16 \\
\hline Mus musculus & 2 & 0.40 & 13 & 1.35 & 10 & 1.88 & 25 & 1.25 \\
\hline Mus sp. & 13 & 2.61 & 18 & 1.87 & 10 & 1.88 & 41 & 2.06 \\
\hline Gliridae & 0 & 0.00 & 3 & 0.31 & 4 & 0.75 & 7 & 0.35 \\
\hline Muscardinus avellanarius & 0 & 0.00 & 3 & 0.31 & 4 & 0.75 & 7 & 0.35 \\
\hline Other prey & 2 & 0.40 & 2 & 0.21 & 8 & 1.50 & 12 & 0.60 \\
\hline Birds & 2 & 0.40 & 0 & 0.00 & 7 & 1.31 & 9 & 0.45 \\
\hline Amphibians & 0 & 0.00 & 1 & 0.10 & 1 & 0.19 & 2 & 0.10 \\
\hline Insects & 0 & 0.00 & 1 & 0.10 & 0 & 0.00 & 1 & 0.05 \\
\hline
\end{tabular}


Table 3. Freeman-Tukey index of niche breadth of Barn Owls at a local scale (for each considered nesting pair)

3. táblázat A gyöngybagoly niche szélességének Freeman-Tukey index értékei lokális skálán (minden figyelembe vett költőpár esetén)

\begin{tabular}{|l|c|c|c|c|c|c|c|c|}
\hline Landscape & \multicolumn{2}{|c|}{ Agricultural } & \multicolumn{4}{c|}{ Mosaic } & \multicolumn{3}{c|}{ Urban } \\
\hline \multicolumn{1}{|c}{ Code/nest } & $F T$ & $95 \% \mathrm{Cl}$ & Code & $F T$ & $95 \% \mathrm{Cl}$ & Code & $F T$ & $95 \% \mathrm{Cl}$ \\
\hline Loc1 & 0.789 & $0.730-0.841$ & Loc5 & 0.777 & $0.744-0.808$ & Loc9 & 0.837 & $0.797-0.872$ \\
\hline Loc2 & 0.687 & $0.621-0.749$ & Loc6 & 0.712 & $0.672-0.750$ & Loc10 & 0.794 & $0.733-0.848$ \\
\hline Loc3 & 0.855 & $0.782-0.914$ & Loc7 & 0.773 & $0.720-0.822$ & Loc11 & 0.825 & $0.766-0.877$ \\
\hline Loc4 & 0.770 & $0.724-0.812$ & Loc8 & 0.789 & $0.735-0.838$ & Loc12 & 0.799 & $0.742-0.850$ \\
\hline
\end{tabular}

$\mathrm{Cl}$ : Confidence Interval

Table 4. Pianka's food niche overlap (O) (below the diagonal) of Barn Owls among landscapes. Above the diagonal are the type I errors of each comparison, obtained by 1000 random permutations in EcoSim $R$

4. táblázat $A$ gyöngybaglyok tájegységek közötti Pianka-féle niche átfedés (O) értékei (az átló alatt). Az átló felett az EcoSim R-ben 1000 random permutáció alapján kapott I. típusú hiba értékei minden összehasonlításban

\begin{tabular}{|l|c|c|c|}
\hline \multicolumn{1}{|c|}{ Landscape } & Agricultural & Mosaic & Urban \\
\hline Agricultural & 1.000 & $<0.001$ & $<0.001$ \\
\hline Mosaic & 0.987 & 1.000 & $<0.001$ \\
\hline Urban & 0.954 & 0.983 & 1.000 \\
\hline
\end{tabular}

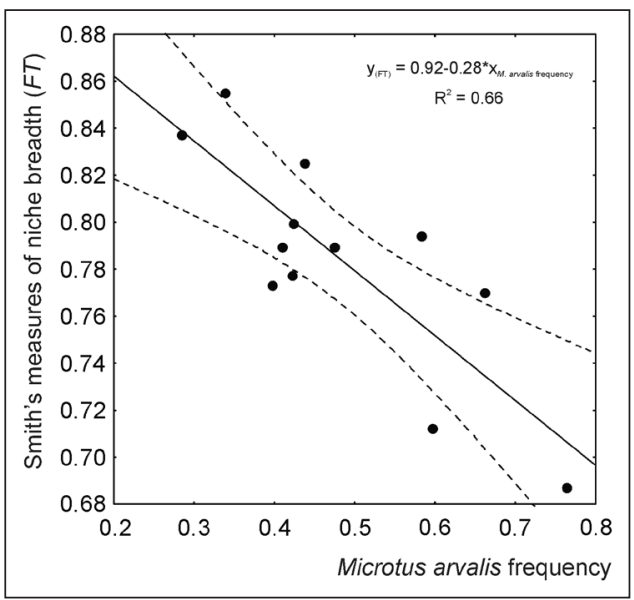

Figure 2. Linear regression between common vole frequency and niche breadth

2. ábra A mezei pocok gyakoriság és a niche szélesség közötti lineáris regresszió

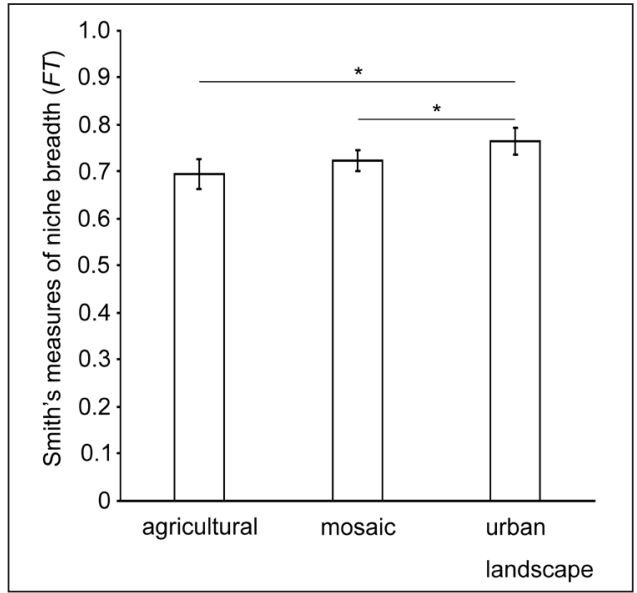

Figure 3. Values of Smith's measures of niche breadth ( $\pm 95 \%$ confidence interval) at landscape level

3.ábra A Smith-féle niche szélesség értéke ( $\pm 95 \%$ konfidencia intervallum) táj szinten 


\section{Discussion}

The feeding habit analysis of Barn Owls from regurgitated pellets is an appropriate method to understand the impact of land use and agricultural practice on the diet composition (Love et al. 2000, Burel et al. 2004), especially on the change of small mammal assemblages in areas dominated by different human activity and land use (de la Peña et al. 2003, González-Fischer et al. 2011, Massa et al. 2014, Torre et al. 2015). The results of the present study demonstrated that the prey consumption of the Barn Owl showed less variation within the boundaries of the larger and intensively cultivated agricultural area. Similar low variability of Barn Owls' diet was reported by some studies in different habitats (González-Fischer et al. 2011) or during long-term study periods (Marti 2010) in agro-ecosystems, as opposing the greater seasonal variability of food compositions (Bontzorolos et al. 2005, González-Fischer et al. 2011, Paspali et al. 2013). Similar to other studies, our result confirmed that small mammals are the dominant prey group in the diet of the Barn Owl, and this owl species is characterized as a typical small mammal specialist (Bosè \& Guidali 2001, Trejo \& Lambertucci 2007, Milchev 2015, Torre et al. 2015). The percent frequency of Striped Field Mouse as a generalist species was significantly higher in the urban landscape. With respect to the relative proportion of this species, our results are consistent with other studies which described the Striped Field Mouse as a permanent but non-dominant prey in the Barn Owl's food composition in the southern part of the Transdanubian region (Horváth et al. 2005, Purger 2014, Szép et al. 2017). Some studies have also pointed out that this rodent species is rather a supplementary component than a crucial or important alternative prey in the diet of Barn Owls (Ruprecht 1979, Milchev 2015). Moreover it is known that Striped Field Mouse is a well spreading species due to its mobility (Spitzenberger \& Engelberger 2014), thus its distribution range has expanded north in the Transdanubian region of Hungary over the last forty years (Bihari 2007) and it was detected in some parts of Austria and Slovakia (Herzig-Straschil 2004, Obuch et al. 2016, Tulis et al. 2016). Despite the distribution of this species in Slovakia, it did not occur in the diet of the Barn Owl in an intensively used farmland (Veselovský et al. 2017). The Striped Field Mouse prefers fields, meadows, wastelands and it is also found in different forests, woodlots patches, in urban and suburban mosaic habitats (Andrzejewski et al. 1978, Gliwicz 1980, Liro \& Szacki 1987, Kozakiewicz et al. 1999, Łopucki et al. 2013, Pieniążek et al. 2017) and it is well adapted to heterogeneous agricultural landscapes (Gentili et al. 2014). Its frequency of occurrence is associated with landscape complexity (Fischer et al. 2011). According to our results the greatest proportion of Striped Field Mouse in pellet samples of urban land reflected the relatedness of this species with urban and suburban habitat patches.

We found that the Common Vole was the most abundant prey in each of the landscape types considered, the same predominance having been reported by other studies in central Europe (Goszczyński 1977, Horváth et al. 2005, Kitowski 2013, Petrovici et al. 2013, Purger 2014, Veselovský et al. 2017). Despite this general predominance, the significant heterogeneity of overall proportion values proved that the consumption frequency of common voles was higher in the agricultural than in the urban landscape. As shown by the heterogeneous percent frequency distribution of common voles and total Microtus genus among 
different landscapes, and the higher relative frequency of both prey categories in agricultural lands, our results agree with those reported in other studies conducted in different geographical regions of Europe (Taylor 1994, de la Peña et al. 2003, Milchev et al. 2006, Milchev 2015, Obuch et al. 2016), and in North-America (Smith et al. 1972, Colvin \& MacLean 1986, Marti 1998, 2010, Hindmarch \& Elliott 2015). In contrast, the higher frequency of mice (Apodemus or Mus) as an alternative prey type was detected principally in European Mediterranean regions (Pezzo \& Morimando 1995, Bontzorolos et al. 2005, Rodrígez \& Peris 2007) while in other studies, the predominance was detected in case of either mice or Microtus voles which was the consequence of different prey availability depending on landscape composition and farming practice (Love et al. 2000, Bosè \& Guidali 2001, Bontzorolos et al. 2005). In North-America, Lyman (2012) reported that mice (Peromyscus) dominated the agricultural prey fauna, whilst voles (Microtus spp.) were the dominant prey group in the pellet samples of non-agricultural lands which was related with the conversion of land use. In addition, Kross et al. (2016) found that mice (Mus, Reithrodontomys) were the most frequently consumed prey item in the Barn Owl's diet, although voles were consumed by the greatest proportion of nesting pairs. This study pointed out the importance of land use gradient both for pest control and for the breeding success of Barn Owls.

The analysis of the Barn Owl's niche breadth showed that its value at the landscape level was significantly higher in the urban than in the agricultural and mosaic landscapes. Our results are in accordance with other studies conducted in Europe (e.g. Milchev 2015, Veselovský et al. 2017), in South-America (Leveau et al. 2006, Gonzalez-Fischer et al. 2011, Teta et al. 2012), and in North-America (Marti et al. 1988, 2010) which reported that the dominance of small mammals, particularly the high frequency of an available and profitable prey in the diet, explained the low values of niche breadth. Our results confirmed that the food niche breadth of Barn Owls was significantly higher in an urban landscape, caused by the decrease of predominant Microtus voles as main prey items (Hindmarch \& Elliott 2015) and by the increase of commensal rodents (rats, house mice) as alternative prey which are associated with human activities (Salvati et al. 2002, Teta et al. 2012, Hindmarch \& Elliott 2015). Hindmarch and Elliott (2015) found that the consumption of predominantly smaller rats increased significantly with increased urbanization within the hunting area of the Barn Owl. Clark and Bunck (1991) pointed out that the increase of these commensal or exotic species' frequency over time indicate the impact of human landscape transformation on the environment of Barn Owls. Despite the different overall niche breadth, based on randomization procedure we detected larger niche overlap between the landscapes considered. This result is consistent with other studies which described very high niche overlap in a comparison of seasons (Pezzo \& Morimando 1995), nest sites (Marti 1988, Bosè \& Guidali 2001), and subsequent years at the same site (Marti 1988, 2010).

According to our results, the regression analysis between percent frequency of Common Voles and niche breadth proved a significant negative relationship. This result is consistent with other studies according to which the higher frequency of voles (Microtus spp.) in the diet affects the evenness component of food-niche, that is, the increase in the frequency of voles leads to a reduction of prey evenness hence to a narrowing of the niche breadth (Marti 1988, 2010, Hindmarch \& Elliott 2015, Milchev 2015). 
Our findings suggest that the diet composition of Barn Owls, mainly their food-niche pattern, reflected prey availability in the comparison of the studied landscapes, which pointed out that it is necessary to examine the dietary difference of Barn Owls at the finer scale of land use.

\section{Acknowledgments}

The Barn Owl pellet analysis in 2016 was carried out with the support of the Hungarian Biodiversity Monitoring System and Duna-Dráva National Park Directorate. Thanks to László Bank, secretary of the Baranya County Group of BirdLife Hungary for providing the pellet samples. Finally, we would like to thank the two anonymous reviewers for many helpful comments.

\section{References}

Andrzejewski, R., Babińska-Werka, J., Gliwicz, J. \& Goszczyński, J. 1978. Synurbization processes in population of Apodemus agrarius. I. Characteristics of populations in an urbanization gradient. - Acta Theriologica 23(20): 341-358.

Askew, N. P., Searle, J. B. \& Moore, N. P. 2007. Agri-environment schemes and foraging of Barn Owls Tyto alba. - Agriculture, Ecosystems \& Environment 118(1): 109-114. DOI: 10.1016/j.agee.2006.05.003

Avery, D. M. 1999. A preliminary assessment of the relationship between trophic variability in southern African Barn Owls Tyto alba and climate. - Ostrich 70(3-4): 179-186. DOI: 10.1080/00306525.1999.9634232

Bernard, N., Michelat, D., Raoul, F., Quéré, J. P., Delattre, P. \& Giraudoux, P. 2010. Dietary response of Barn Owls (Tyto alba) to large variations in populations of Common Voles (Microtus arvalis) and European Water Voles (Arvicola terrestris). - Canadian Journal of Zoology 88(4): 416-426. DOI: 10.1139/Z10-011

Bihari, Z. 2007. Pirók erdeiegér (Apodemus agrarius Pallas, 1771) [Striped Field Mouse Apodemus agrarius (Pall.)]. - In: Bihari, Z., Csorba, G. \& Heltai, M. (eds.) Magyarország emlöseinek atlasza [Atlas of mammals in Hungary]. - Kossuth Kiadó, Budapest, pp. 179-180.

Bontzorlos, V. A., Peris, S. J., Vlachos, C. G. \& Bakaloudis, D. E. 2005. The diet of Barn Owl in the agricultural landscapes of central Greece. - Folia Zoologica 54(1-2): 99-100.

Bosé, M. \& Guidali, F. 2001. Seasonal and geographic differences in the diet of the Barn Owl in an agro-ecosystem in northern Italy. - Journal of Raptor Research 35(3): 240-246.

Burel, F., Butet, A., Delettre, Y. R. \& de La Peña, N. M. 2004. Differential response of selected taxa to landscape context and agricultural intensification. - Landscape and Urban Planning 67(1-4): 195-204. DOI: 10.1016/ S0169-2046(03)00039-2

Campbell, R. W., Manuwal, D. A. \& Harestad, A. S. 1987. Food habits of the Common Barn Owl in British Columbia. - Canadian Journal of Zoology 65(3): 578-586. DOI: 10.1139/z87-090

Capizzi, D. \& Luiselli, L. 1998. A comparative study of the variability of owl diets in three localities of central Italy. - Revue d'Ecologie (La Terre et la Vie) 53: 367-385.

Charter, M., Izhaki, I., Meyrom, K., Motro, Y. \& Leshem, Y. 2009. Diets of Barn Owls differ in the same agricultural region. - The Wilson Journal of Ornithology 121(2): 378-383. DOI: 10.1676/08-083.1

Clark, D. R. \& Bunck, C. M. 1991. Trends in North American small mammals found in Common Barn Owl dietary studies. - Canadian Journal of Zoology 69: 3093-3102. DOI: 10.1139/z91-435

Colvin, B. A. \& McLean, E. B. 1986. Food habits and prey specificity of the Common Barn Owl in Ohio. - Ohio Journal of Science 86(3): 76-80.

Cooke, D., Nagle, A., Smiddy, P., Fairley, J. \& Ó Muircheartaigh, I. 1996. The diet of the Barn Owl Tyto alba in County Cork in relation to land use. - Biology and Environment 96(2): 97-111.

de Bruijn, O. 1994. Population ecology and conservation of the Barn Owl Tyto alba in farmland habitats in Liemers and Achterhoek (The Netherlands). - Ardea 82: 1-109. 
de la Peña, N. M., Butet, A., Delettre, Y., Paillat, G., Morant, P., Le Du, L. \& Burel, F. 2003. Response of the small mammal community to changes in western French agricultural landscapes. - Landscape Ecology 18(3): $265-278$.

Devictor, V., Clavel, J., Julliard, R., Lavergne, S., Mouillot, D., Thuiller, W., Venail, P., Villéger, S. \& Mouquet, N. 2010. Defining and measuring ecological specialization. - Journal of Applied Ecology 47(1): 15-25. DOI: 10.1111/j.1365-2664.2009.01744.x

Fischer, C., Thies, C. \& Tscharntke, T. 2011. Small mammals in agricultural landscapes: opposing responses to farming practices and landscape complexity. - Biological Conservation 144(3): 1130-1136. DOI: 10.1016/j. biocon.2010.12.032

Frey, C., Sonnay, C., Dreiss, A. \& Roulin, A. 2011. Habitat, breeding performance, diet and individual age in Swiss Barn Owls (Tyto alba). - Journal of Ornithology 152(2): 279-290. DOI: 10.1007/s10336-010-0579-8

Gentili, S., Sigura, M. \& Bonesi, L. 2014. Decreased small mammals species diversity and increased population abundance along a gradient of agricultural intensification. - Hystrix, the Italian Journal of Mammalogy 25(1): 39-44. DOI: 10.4404/hystrix-25.1-9246

Gliwicz, J. 1980. Ecological aspects of synurbization of Striped Field Mouse Apodemus agrarius (Pall.) - Wiadomosci Ekologiczne 26: 185-196.

González-Fischer, C. M., Codesido, M., Teta, P. \& Bilenca, D. 2011. Seasonal and geographic variation in the diet of Barn Owls (Tyto alba) in temperate agroecosystems of Argentina. - Ornitología Neotropical 22: 295-305.

Goszczyński, J. 1977. Connections between predatory birds and mammals and their prey. - Acta Theriologica 22(30): 399-430.

Gotelli, N. J., Hart, E. M. \& Ellison, A. M. 2015. EcoSimR: Null model analysis for ecological data. R Package Version 0.1.0. Available at github. com/gotellilab/EcoSimR. Accessed August, 29, 2017

Heisler, L. M., Somers, C. M. \& Poulin, R. G. 2014. Rodent populations on the northern Great Plains respond to weather variation at a landscape scale. - Journal of Mammalogy 95(1): 82-90. DOI: 10.1644/13-MAMM-A-115.1

Herrera, C. M. 1974. Trophic diversity of the Barn Owl Tyto alba in continental Western Europe. - Ornis Scandinavica 5(2): 181-191. DOI: 10.2307/3676061

Herrera, C. M. \& Hiraldo, F. 1976. Food-niche and trophic relationships among European owls. - Ornis Scandinavica 7(1): 29-41. DOI: $10.2307 / 3676172$

Herrera, C. M. \& Jaksić, F. M. 1980. Feeding ecology of the Barn Owl in central Chile and southern Spain: a comparative study. - The Auk 97(4): 760-767.

Herzig-Straschil, B., Bihari, Z. \& Spitzenberger, F. 2003. Recent changes in the distribution of the Field Mouse (Apodemus agrarius) in the western part of the Carpathian basin. - Annalen des Naturhistorischen Museums in Wien 105B: 421-428.

Hindmarch, S. \& Elliott, J. E. 2015. A specialist in the city: the diet of Barn Owls along a rural to urban gradient. - Urban Ecosystems 18(2): 477-488. DOI: 10.1007/s11252-014-0411-y

Hindmarch, S., Krebs, E. A., Elliott, J. E. \& Green, D. J. 2012. Do landscape features predict the presence of Barn Owls in a changing agricultural landscape? - Landscape and Urban Planning 107(3): 255-262. DOI: 10.1016/j.landurbplan.2012.06.010

Horváth, G. F., Molnár, D., Németh, T. \& Csete, S. 2005. Landscape ecological analysis of Barn Owl pellet data from the Drava lowlands, Hungary. - Natura Somogyiensis 7: 179-189.

Jaksić, F. M., Seib, R. L. \& Herrera, C. M. 1982. Predation by the Barn Owl (Tyto alba) in Mediterranean habitats of Chile, Spain and California: A comparative approach. - American Midland Naturalist 107: 151-162. DOI: $10.2307 / 2425196$

Jaksić, F. M. \& Delibes, M. 1987. A comparative analysis of food-niche relationships and trophic guild structure in two assemblages of vertebrate predators differing in species richness: causes, correlations, and consequences. - Oecologia 71(3): 461-472. DOI: 10.1007/BF00378722

Jaksić, F. M., Feinsinger, P. \& Jiménez, J. E. 1993. A long-term study on the dynamics of guild structure among predatory vertebrates at a semi-arid Neotropical site. - Oikos 67: 87-96. DOI: 10.2307/3545099

Jaksić, F. M., Silva, S. I., Meserve, P. L. \& Gutierrez, J. R. 1997. A long-term study of vertebrate predator responses to an El Nino (ENSO) disturbance in western South America. - Oikos 78: 341-354. DOI: 10.2307/3546302

Kitowski, I. 2013. Winter diet of the Barn Owl (Tyto alba) and the Long-eared Owl (Asio otus) in Eastern Poland. - North-western Journal of Zoology 9(1): 16-22.

Klein, R. G. \& Cruz-Uribe, K. 1984. The analysis of animal bones from archeological sites. - University of Chicago Press, Chicago, IL.

Krebs, C. J. 1999. Ecological Methodology. - Addison Wesley Educational Publishers Inc. Menlo Park, CA. 
Kozakiewicz, M., Gortat, T., Kozakiewicz, A. \& Barkowska, M. 1999. Effects of habitat fragmentation on four rodent species in a Polish farm landscape. - Landscape Ecology 14(4): 391-400.

Kross, S. M., Bourbour, R. P. \& Martinico, B. L. 2016. Agricultural land use, barn owl diet, and vertebrate pest control implications. - Agriculture, Ecosystems \& Environment 223: 167-174. DOI: 10.1016/j.agee.2016.03.002

Kryštufek, B. \& Macholán, M. 1998. Morphological differentiation in Mus spicilegus and the taxonomic status of mound-building mice from the Adriatic coast of Yugoslavia. - Journal of Zoology 245(2): 185-196. DOI: 10.1111/j.1469-7998.1998.tb00086.x

Leader, Z., Yom-Tov, Y. \& Motro, U. 2010. Diet comparison between two sympatric owls - Tyto alba and Asio Otus - in the Negev Desert, Israel. - Israel Journal of Ecology \& Evolution 56(2): 207-216. DOI: 10.1560/ IJEE.56.2.207

Leveau, L. M., Teta, P., Bogdaschewsky, R. \& Pardiñas, U. F. 2006. Feeding habits of the Barn Owl (Tyto alba) along a longitudinal-latitudinal gradient in central Argentina. - Ornitología Neotropical 17(3): 353-362.

Liro, A., \& Szacki, J. 1987. Movements of Field Mice Apodemus agrarius (Pallas) in a suburban mosaic of habitats. - Oecologia 74(3): 438-440. DOI: 10.1007/BF00378942

Łopucki, R., Mróz, I., Berliński, Ł. \& Burzych, M. 2013. Effects of urbanization on small-mammal communities and the population structure of synurbic species: an example of a medium-sized city. - Canadian Journal of Zoology 91(8): 554-561. DOI: 10.1139/cjz-2012-0168

Lovari, S., Renzoni, A. \& R. Fondi 1976. The predatory habits of the Barn Owl (Tyto alba Scopoli) in relation to vegetation cover. - Bollettino di Zoologia Italiana 43: 173-191. DOI: 10.1080/11250007609434894

Love, R. A., Webon, C., Glue, D. E. \& Harris, S. 2000. Changes in the food of British Barn Owls (Tyto alba) between 1974 and 1997. - Mammal Review 30(2): 107-129. DOI: 10.1046/j.1365-2907.2000.00060.x

Lyman, R. L. 2012. Rodent-prey content in long-term samples of Barn Owl (Tyto alba) pellets from the northwestern United States reflects local agricultural change. - The American Midland Naturalist 167(1): 150-163. DOI: $10.1674 / 0003-0031-167.1 .150$

Macholán, M. 1996. Morphometric analysis of European house mice. - Acta Theriologica 41(3): 255-275.

Marti, C. D. 1974. Feeding ecology of four sympatric owls. - The Condor 76(1): 45-61. DOI: 10.2307/1365983

Marti, C. D. 1988. A long-term study of food-niche dynamics in the Common Barn Owl: comparisons within and between populations. - Canadian Journal of Zoology 66(8): 1803-1812. DOI: 10.1139/z88-261

Marti, C. D. 2010. Dietary trends of Barn Owls in an agricultural ecosystem in Northern Utah. - Wilson Journal of Ornithology 122(1): 60-67. DOI: 10.1676/09-025.1

März, R. 1972. Gewöll- und Rupfungskunde [The science of pellets and pluck]. - Akademie Verlag, Berlin (in German)

Massa, C., Teta, P. \& Cueto, G. R. 2014. Effects of regional context and landscape composition on diversity and composition of small rodent assemblages in Argentinian temperate grasslands and wetlands. - Mammalia 78(3): 371-382. DOI: 10.1071/AM08115

McDowell, M. C. \& Medlin, G. C. 2009. The effects of drought on prey selection of the Barn Owl (Tyto alba) in the Strzelecki Regional Reserve, north-eastern South Australia. - Australian Mammalogy 31(1): 47-55. DOI: 10.1071/AM08115

Milana, G., Lai, M., Maiorano, L., Luiselli, L. \& Amori, G. 2016. Geographic patterns of predator niche breadth and prey species richness. - Ecological Research 31(1): 111-115. DOI 10.1007/s11284-015-1319-6

Milchev, B., Boev, Z. \& Kodjabashev, N. 2006. Breeding distribution and diet composition of the Barn Owl Tyto alba (Scopoli, 1769), (Aves: Strigiformes) in the North-Western Upper Thracian plain (Bulgaria). - Acta Zoologica Bulgarica 58(1): 83-92.

Milchev, B. 2015. Diet of Barn Owl Tyto alba in Central South Bulgaria as influenced by landscape structure. Turkish Journal of Zoology 39(5): 933-940. DOI: 10.3906/zoo-1409-24

Milchev, B. 2016. Dietary comparison of coexisting Barn Owl (Tyto alba) and Eagle Owl (Bubo bubo) during consecutive breeding seasons. - Animal Biology 66(2): 219-228. DOI: 10.1163/15707563-00002499

Obuch, J., Danko, Š. \& Noga, M. 2016. Recent and subrecent diet of the Barn Owl (Tyto alba) in Slovakia. - Slovak Raptor Journal 10(1): 1-50. DOI: 10.1515/srj-2016-0003

Paspali, G., Oruci, S., Koni, M., Wilson, I. F., Krystufek, B. \& Bego, F. 2013. Seasonal variation of small mammals in the diet of the Barn Owl (Tyto alba) in the Drinos River valley, southern Albania. - Turkish Journal of Zoology 37(1): 97-105. DOI: 10.3906/zoo-1203-25

Petrovici, M., Molnar, P. \& Sándor, A. D. 2013. Trophic niche overlap of two sympatric owl species (Asio otus Linnaeus, 1758 and Tyto alba Scopoli, 1769) in the North-Western part of Romania. - North-Western Journal of Zoology 9(2): 250-256. 
Pezzo, F. \& Morimando, F. 1995. Food habits of the Barn Owl, Tyto alba, in a Mediterranean rural area: Comparison with the diet of two sympatric carnivores. - Italian Journal of Zoology 62(4): 369-373. DOI: $10.1080 / 11250009509356091$

Pianka, E. R. 1974. Niche overlap and diffuse competition. - Proceedings of the National Academy of Sciences 71(5): 2141-2145.

Pieniążek, A., Sokół, M. \& Kozakiewicz, M. 2017. Ecological characteristics of two closely related rodent species in urban environment -Permanent inhabitant vs newcomer. - Natural Resources 8(2): 69-80. DOI: 10.4236/ nr.2017.82005

Purger, J. J. 2014. Survey of the small mammal fauna in north-western Somogy county (Hungary), based on Barn Owl Tyto alba (Scopoli, 1769) pellet analysis. - Natura Somogyiensis 24: 293-304.

R Development Core Team 2016. R: A Language and Environment for Statistical Computing. - R Foundation for Statistical Computing, Vienna

Rodríguez, C. \& Peris, S. J. 2007. Habitat associations of small mammals in farmed landscapes: implications for agri-environmental schemes. - Animal Biology 57(3): 301-314. DOI: 10.1163/157075607781753092

Ruprecht, A. L. 1979. Food of the Barn Owl, Tyto alba guttata (CL Br.) from Kujawy. - Acta Ornithologica 16(19): 493-511.

Sahores, M. \& Trejo, A. 2004. Diet shift of Barn Owls (Tyto alba) after natural fires in Patagonia, Argentina. Journal of Raptor Research 38: 174-177. DOI: 10.3356/0892-1016(2007)41[277:FHOBOA]2.0.CO;2

Salvati, L., Manganaro, A. \& Ranazzi, L. 2002. Aspects of the ecology of the Barn Owl Tyto alba breeding in a Mediterranean area. - Bird Study 49(2): 186-189. DOI: 10.1080/00063650209461264

Smith, D. G., Wilson, C. R. \& Frost, H. H. 1972. Seasonal food habits of Barn Owls in Utah. - The Great Basin Naturalist 32: 229-234.

Smith, E. P. 1982. Niche breadth, resource availability, and inference. - Ecology 63(6): 1675-1681.

Sokal, R. R. \& Rohlf, F. J. 1995. The principles and practice of statistics in biological research. - W. H. Freeman and Company, New York, NY.

Sokal, R. R. \& Rohlf, F. J. 1997. Biometry. - W. H. Freeman and Co., New York

Spitzenberger, F. \& Engelberger, S. 2014. A new look at the dynamic western distribution border of Apodemus agrarius in Central Europe (Rodentia: Muridae). - Lynx Nova 45: 69-79.

Szép, D., Klein, Á. \& Purger, J. J. 2017. The prey composition of the Barn Owl (Tyto alba) with respect to landscape structure of its hunting area (Zala County, Hungary). - Ornis Hungarica 25(2): 51-64. DOI: 10.1515/ orhu-2017-0015

Taylor, I. 1994. Barn Owls. Predator-prey relationships and conservation. - Cambridge University Press, Cambridge

Teta, P., Hercolini, C. \& Cueto, G. 2012. Variation in the diet of Western Barn Owls (Tyto alba) along an urban-rural gradient. - The Wilson Journal of Ornithology 124(3): 589-596. DOI: 10.1676/11-173.1

Torre, I., Gracia-Quintas, L., Arrizabalaga, A., Baucells, J. \& Díaz, M. 2015. Are recent changes in the terrestrial small mammal communities related to land use change? A test using pellet analyses. - Ecological Research 30(5): 813-819. DOI 10.1007/s11284-015-1279-x

Trejo, A. \& Lambertucci, S. 2007. Feeding habits of Barn Owls along a vegetative gradient in northern Patagonia. - Journal of Raptor Research 41(4): 277-287. DOI: 10.3356/0892-1016(2007)41[277:FHOBOA]2.0.CO;2

Tulis, F., Baláž, M., Obuch, J. \& Šotnár, K. 2015. Responses of the Long-eared Owl Asio otus diet and the numbers of wintering individuals to changing abundance of the Common Vole Microtus arvalis. - Biologia 70(5): 667-673. DOI: 10.1515/biolog-2015-00

Tulis, F., Ambros, M., Baláz, I., Ziak, D., Sládkovicová, V. H., Miklós, P., Dudich, A., Stollmann, A., Klimant, P., Somogyi, B. \& Horváth, G. 2016. Expansion of the Striped field Mouse (Apodemus agrarius) in the south-western Slovakia during 2010-2015. - Folia Oecologica 43(1): 64-72.

Veselovský, T., Bacsa, K. \& Tulis, F. 2017. Barn Owl (Tyto alba) diet composition on intensively used agricultural land in the Danube Lowland. - Acta Universitatis Agriculturae et Silviculturae Mendelianae Brunensis 65(1): 225-233. DOI: 10.11118/actaun201765010225

Yalden, D. W. \& Morris, P. A. 1990. Owl pellet analysis. - The Mammal Society, London

Yalden, D. W. 1977. Identification of remains in owl pellets. - The Mammal Society, London 